\title{
Experiences of success in industrial plants projects
}

\section{Experiencias exitosas en proyectos de plantas industriales}

\author{
Nuria Forcada*1, Miquel Casals*, M arta G angolells*, Xavier Roca*, Alba Fuertes* \\ * Universidad Politécnica de Catalunya, Barcelona, SPAIN
}

Fecha de recepción: 19/11/2007 Fecha de aceptación: 10/ 04/ 2008 PAG. 82 - 93

Abstract

Success has always been the ultimate goal of construction projects, and different researchers have tried to evaluate it using different factors. Although specialized industrial construction usually involves very large scale projects with a high degree of technological complexity, research has mostly focused on civil and residential success factors. Experiences in Industrial Plants projects can help to improve project management and productivity in such a specialized sector. In this kind of projects, the contractual arrangement is one of the core differences on Project management and thus project success. This research seeks to develop a schema for classifying critical success factors as well as a methodology for evaluating projects. This methodology was adopted to evaluate critical success factors in Industrial Plants projects with different contractual arrangements. Findings suggest that although the construction stage has been the focus of many studies, the first stages are decisive for the success of projects; contract construction projects consider project planning to be more important; lump sum contract construction projects give greater importance to monitoring the benefits; bidding competition projects consider the available technology with greater rigor, etc. The results indicate that different Industrial Plants projects involve different success factors and management characteristics to achieve project objectives.

Keywords: Industrial plants, construction industry, project management, success factors, project evaluation

Resumen

En cualquier proyecto de construcción el principal objetivo es que sea exitoso y por lo tanto a lo largo del tiempo diferentes investigadores han tratado de evaluar los factores que influyen en el éxito de proyectos. En el ámbito de la construcción estas investigaciones se han enfocado principalmente a obras civiles y residenciales. Este artículo muestra resultados que provienen de proyectos de construcción industrial especializada que incluyen proyectos de gran escala con un alto grado de complejidad tecnológica, relaciones contractuales más complejas que en las obras residenciales, mayor dificultad en la gestión de proyectos, etc. Las experiencias exitosas en proyectos de Plantas Industriales pueden ayudar a mejorar la gestión de proyectos y la productividad en un sector tan especializado como es la construcción industrial. En esta investigación se desarrolla un esquema de clasificación de factores críticos para el éxito así como una metodología para evaluar proyectos. Esta metodología fue adoptada para evaluar factores críticos para el éxito en distintos proyectos de Plantas Industriales con diferentes relaciones contractuales. Las conclusiones sugieren que aunque la etapa de construcción haya sido el foco de muchos estudios, las primeras etapas son decisivas para el éxito de proyectos; los proyectos con un sistema de contratación tradicional consideran la planificación del proyecto como lo más importante; los proyectos "llave en mano" dan una importancia mayor al monitoreo de los beneficios; los proyectos que se llevan a concurso consideran la tecnología disponible con mayor rigor, etc. Los resultados indican que distintos proyectos de Plantas Industriales requieren de diferentes factores de éxito y características de gerencia para alcanzar sus objetivos.

Palabras Clave: Plantas industriales, sector de la construcción, gestión de proyectos, factores para el éxito, evaluación de proyectos

\section{Introduction}

The construction process is subjected to the influence of highly variable and sometimes unpredictable factors. The construction team, which includes architects, engineers, subcontractors, and others, changes from one job to the next. Consequently, construction projects are

\footnotetext{
1 Autor de correspondencia / Corresponding author: C/Colom 11, Ed. TR-5, Terrasa, Barcelona. Spain. E-mail: nuria.forcada@upc.edu
}

typified by their complexity and diversity and by the non standardized nature of their production (Clough et al., 2000).

Construction is normally classified as: civil engineering and building construction. In Spain, from the building construction perspective, $90 \%$ of projects are residential buildings (SEOPAN, 2007). 
M any studies evaluate critical success factors in residential buildings due to its standardisation and simplicity. Although non-residential buildings is the $17 \%$ of the total construction in Spain and industrial construction is only the $18 \%$ of this subsector, the acceleation fo the private demands is allowing a light recuperation of this segment. However, very rarely researchers study this specific market (SEO PAN, 2007).

Currently, numerous European, N orth American, and Asian industrial firms are likely to settle down in Spain. They will be looking for Spanish construction companies to carry out their work, particularly on large projects. M oreover, separate bids from numerous foreign construction firms are not unusual. In this environment of heightened competition, good project management and improved productivity are more and more important. A study of success factors in Industrial Plants Projects can help Spanish and foreign companies interested in getting into the Spanish industrial construction market to plan their strategies and achieve their objectives.

The various contractual arrangements reflect fundamental differences in the allocation of responsibility and in the success of the project. An owner may have inhouse capacities to handle the management in every stage of the entire process (lump sum construction), or may seek professional advice and services for the work in some stages (contract construction).

The owner can also select designers and contractors on the basis of competitive bidding, negotiation, or some combination of the two. A large proportion of the construction in Spain is done by contractors who obtain their work through competitive bidding. Competitive bidding of public projects is normally required by law. At times, it can be advantageous for an owner to negotiate a contract for its project with a pre-qualified contractor or small group of contractors. It is common practice for an owner to forgo the competitive bidding process and to handpick a contractor on the basis of its reputation and overall qualifications to do the job. This type of contract normally is limited to privately financed work.

Under any contractual arrangement, although the parties perceive project success or failure differently, the success of a project is defined as achieving the initial objectives. Every decision-making problem is oriented towards the selection of the correct strategies for achieving objectives, and depends on the assumptions associated with different scenarios. Therefore, the definition of the critical success factors and the analysis of risks are necessary to analyze the achievement of project objectives (Özdogan I. and Birgönül, M.T., 2000).
Although there are no authors were unable to uncover studies in Industrial Plants Construction, most of the work in construction project management has traditionally focused on project scheduling problems, assuming that the development of better scheduling techniques would result in better management and thus the successful completion of projects. However, there are many factors beyond the control of management which could determine the success or failure of a project. Most of the early studies in this field focused on the reasons for project failure rather than the reasons for project success.

Industrial firms who pay close attention to the peculiar characteristics of the industrial construction industry and its changing operating environment will be able to take advantage of favorable conditions and to avoid pitfalls. Several factors are particularly noteworthy because of their significant impacts on the quality, cost and time of construction. Therefore, combinations of these factors at different stages usually result in the success or failure of projects.

\section{Research methodology}

The aim of this paper is to define a methodology for evaluating projects and to analyze success experiences in different types of projects with the final objective of getting feedback to improve project management in industrial construction projects. Furthermore, those companies interested in getting into the Spanish industrial market would have real information on the working methodologies in the industrial construction sector in Spain.

A critical review of the current literature on critical success factors for construction projects allowed the authors to formulate the following methodology for achieving their research objectives:

1. A thorough and critical review of the literature on critical success factors for construction projects.

2. Definition of a Success and Failure Evaluation System (SFES) for all project stages from the literature review.

3. Evaluations of industrial construction projects using SFES with different contractual arrangements: lump sum vs. contract construction and bidding competition vs. negotiated contract.

4. Development of conclusions by contractual arrangement with the aim of identifying the factors that affect projects and providing solutions for future industrial construction projects. 


\section{Factors affecting project success}

Success and failure factors were first introduced by Rubin and Seeling (1967) and followed by Avots (1969) who investigated the impact of a project manager's experience on the project's success or failure. Baker, Murphy and Fisher (1983) suggested that instead of using time, cost and performance as measures for project success, perceived performance should be the measure, while Maloney (1990) stated that the success of the project was based on client satisfaction and it must be evaluated through the project performance in terms of cost, schedule and quality.

On the other hand, Freeman and Beale (1992) and Riggs et al., (1992) suggested that less tangible project success factors should also be recognized. In terms of classification methods, Schultz, Slevin and Pinto (1987) classified critical factors as strategic or tactical. In their follow-up work, Pinto and Slevin (1989) and Pinto and Prescott (1990), Belassi and Tukel (1996), Shenhar et al., (1997), Chan et al., (2004) and others identified the relative importance of success factors for each stage of the project.

Lim and Mohamed (1999) further classified project success into two categories: the macro and micro viewpoints. However, Brown and Adams (2000) and N ewcombe (2000) reported that time, cost and quality were still the prime project objectives.

From the literature review, it can be concluded that the analysis of traditional success factors (time, cost and quality) are not enough for the project success. These factors should be complemented with more intangible factors such as client satisfaction, performance, management, etc.

\section{Basis for the development of a success and failure evaluation system}

\subsection{Success factors}

From the previous analysis, a number of variables influencing the success of project implementation were identified. A careful study of previous literature suggests that the most accurate and extensive model to define all the Critical Success Factors in whatever construction project is the one described by Chan et al., (2004). Therefore, this study will be based in this model and will try to validate this model theoretical model in real industrial plants projects.

From this model, the main structure of Critical Success Factors is: Project management factors, Project related factors, External factors, Tendering method, and Human-related factors (See Figure 1). N evertheless, all of them based on the most important goal: client satisfaction.

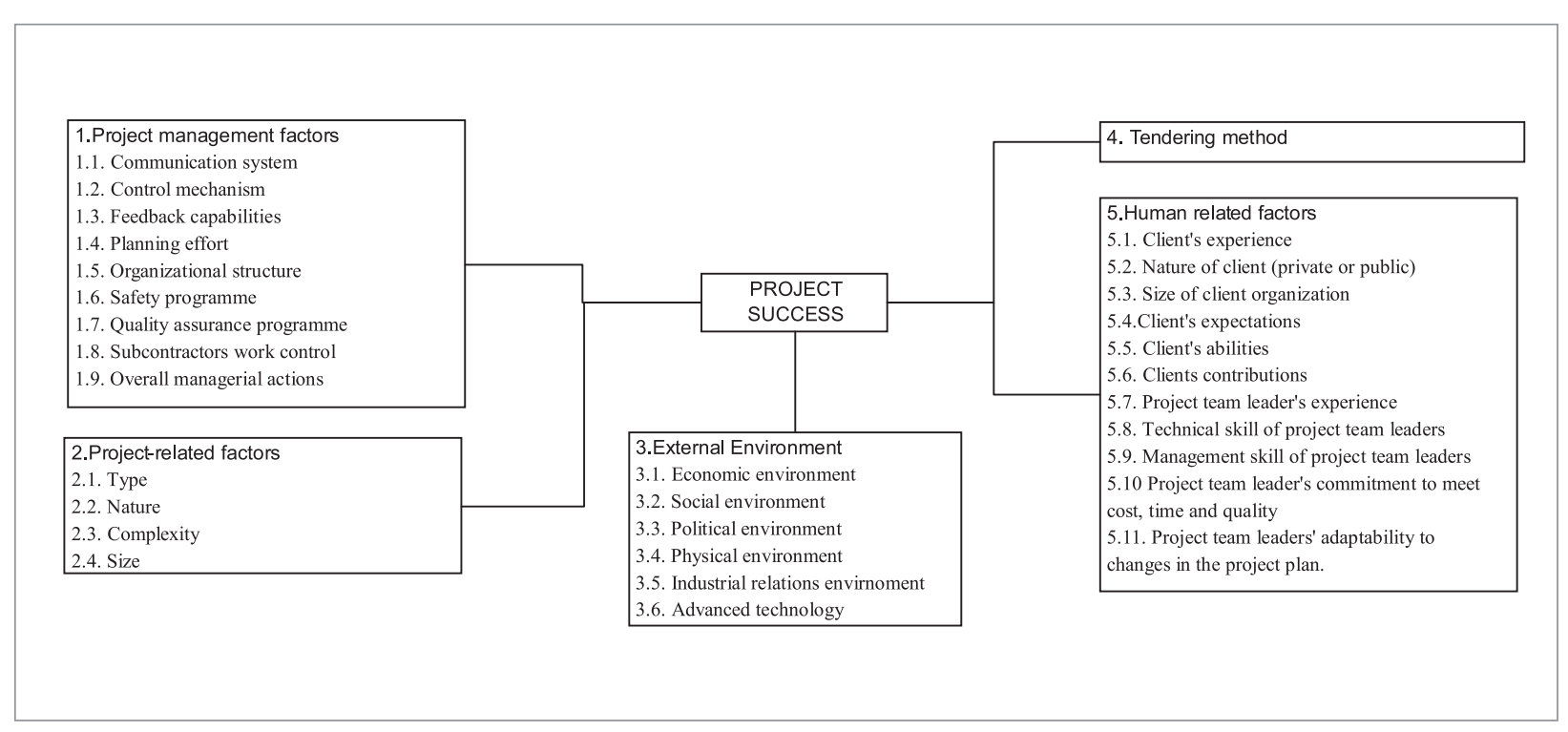

Figure 1. Framework for critical success factors and variables 
The success factors related to 'project management' include the communication system, control mechanism, feedback capabilities, planning effort, organizational structure, safety program, quality assurance program, monitoring the work of subcontractors and overall managerial actions (Belout, 1998; Chua et al., 1999; Walker and Vines, 2000; Chan's et al., 2004; Gann and Whyte, 2003).

Walker (1995), Songer and Molenaar (1997), Belout (1998), Chua et al., (1999), Dissanayaka and Kumaraswamy (1999) and Kumaraswamy and Chan (1999) postulated project characteristics as a factor affecting the success of a construction project. Therefore, the variables used in this research to measure 'project related factors' are the type, nature, complexity and size of the project.

Various researchers support 'environment' as a factor affecting the project success (Kaming et al., 1997, Songer and Molenaar 1997, Chua et al., 1999; Walker and Vines, 2000). 'Environment' is defined as all external influences on the construction process, including social, political and technical systems. The variables used in this system to measure this factor are the economic, social, political, physical and industrial relations environment and the level of technological advancement.

A number of researchers identified the importance of 'tendering methods' (Pocock et al. 1997a, 1997b; Walker 1997; Kumaraswamy and Chan 1999; Walker and Vines 2000). Therefore, the procedures adopted for the selection of the project team and in particular the main contractor are used to measure this factor.

Chua et al., (1999) defined project participants such as the client, the designer, the contractor and the project manager (human-related factors) as the key players. Walker (1995), Chan and Kumaraswamy (1997), Songer and M olenaar (1997) and Dissanayaka and Kumaraswamy (1999) considered the influence of the client as a significant factor on construction time performance and defined the client-related factors such as client type and experience, knowledge of construction project organization, project financing, client confidence in the construction team, etc. Chan and Kumaraswamy (1997) and Gann and Whyte (2003) considered that designers play a vital role as they are involved from inception to completion of a project so quality design is a key issue for the success of a project. Contractor's experience is also a key success factor on the construction stage of a project (Chan and Kumaraswamy 1997; Dissanayaka and Kumaraswamy 1999). Finally, the project manager is another key stakeholder in a construction project and his competence is a critical factor affecting project planning, scheduling, and communication (Belassi and Tukel 1996).

The variables used in this research to measure human-related factors are client's experience, nature and size, client's expectations, abilities and contributions, project team leader's experience, technical and management skills commitment to meet cost, time and quality and adaptability to changes in the project plan.

\subsection{Success factors and project stages}

The construction stage is where all the project goals of the contractual parties like time, cost, performance, quality, safety and so on are established and put to test. The degree of effectiveness of the project management functions and the degree of success of the project goals will determine the degree to which the individual party will perceive the project as being successful from its own viewpoint (Lim and Mohamed 1999). It is interesting to note that the construction stage has been the focus of many studies. It is during the construction stage that the demands for time, cost and quality requirements become most acute. In practice there are plenty of examples in which a project takes a long time to be decided, planned, designed, tendered, awarded and signed. Finally, when it comes to the construction stage, all the past inadequacies of every preceding stage appear and everything must be done within the schedule and budget given. We must therefore be aware that there may be important issues that are not properly addressed in the preceding stage.

Therefore, the critical success factors defined above can come up as the project progresses from the conceptual stage to the finalization stage. Figure 2 depicts the complete project stages as a project progresses.

Based on the previous classification of Critical Success Factors and the stages of a project a set of parameters $(\mathrm{P}) /$ questions $(\mathrm{Q})$ to evaluate all critical success factors from the conception until the finalization stage of a project were formulated. These questions were defined in cooperation with an expert group of project managers who were asked to formulate representative questions to stablish the different critical success factors. However, many factors were identified in different stages but the questions defined to consider them where different. Consecuently, evaluation questions were organised according tho the different stages of the project.

Table 1 show the relationship between the parameters / questions for each stage of the construction process and the different factors / variables described above. 


\begin{tabular}{|l|l|l|l|l|}
\hline Conceptual & Planning & Facsign & Factors \\
\hline Factors & & Factors & Factors \\
\hline
\end{tabular}

Figure 2. Project life cycle

Table 1. Relation between success / failure factors and parameters in the conceptual stage

\begin{tabular}{|c|c|c|c|c|c|c|}
\hline & Parameters / questions & $\begin{array}{l}\text { Project } \\
\text { Management } \\
\text { factors }\end{array}$ & $\begin{array}{l}\text { Project- } \\
\text { related } \\
\text { factors }\end{array}$ & $\begin{array}{l}\text { External } \\
\text { environmental } \\
\text { factors }\end{array}$ & $\begin{array}{l}\text { Tendering } \\
\text { method }\end{array}$ & $\begin{array}{l}\text { Human- } \\
\text { related } \\
\text { factors }\end{array}$ \\
\hline 1 & $\begin{array}{l}\text { Are you sure of what business units or strategic functions } \\
\text { support the proposal and whether they fit in the strategy? }\end{array}$ & 1.5 & & & 4 & \\
\hline 2 & Is the proposal attractive in size, saving, contribution, etc.? & & 2.4 & 3 & & \\
\hline 3 & Is the proposal attractive for the client or user? & & & & & 5.4 \\
\hline 4 & $\begin{array}{l}\text { If there are competitors with similar capacity, be sure that } \\
\text { the proposal can offer a competitive advantage }\end{array}$ & & & 3.1 & & \\
\hline 5 & Is the proposal revised and accepted? & $1.2,1.7$ & & & & \\
\hline 6 & Have you got a sponsor? & 1.5 & & & 4 & \\
\hline 7 & Have you got a project director? & 1.5 & & & & \\
\hline 8 & $\begin{array}{l}\text { Have you got enough resources for the execution of the } \\
\text { conceptual stage? }\end{array}$ & & & & & \\
\hline 9 & Is it possible to carry out the project with current technology? & & 2.3 & 3.6 & & \\
\hline 10 & $\begin{array}{l}\text { Are you sure of what business units or strategic functions } \\
\text { support the proposal and whether they fit in the strategy? }\end{array}$ & 1.5 & & & & \\
\hline 11 & Is the proposal attractive? & & 2.2 & 3 & & \\
\hline 12 & Is the previous stage completed? & & & & & \\
\hline 13 & Is the general investment acceptable? & & & 3.1 & & $5.3,5.4$ \\
\hline 14 & $\begin{array}{l}\text { Is there a detailed planning of resources and a plan of } \\
\text { costs for the planning stage? }\end{array}$ & 1.4 & & & & \\
\hline 15 & $\begin{array}{l}\text { Is there a detailed planning of resources and a plan of } \\
\text { costs for the whole project? }\end{array}$ & 1.4 & & & & \\
\hline 16 & Have you got a sponsor for the project? & 1.5 & & & 4 & \\
\hline 17 & Have you got a project director? & 1.5 & & & & \\
\hline 18 & $\begin{array}{l}\text { Have you got enough resources for the execution of the } \\
\text { definition stage? }\end{array}$ & & & 3.1 & & $5.3,5.4$ \\
\hline 19 & $\begin{array}{l}\text { Is the organization prepared to support the development } \\
\text { of the technology? If not, Is it possible to carry out the } \\
\text { project with current knowledge? }\end{array}$ & & & $3.1,3.6$ & & $\begin{array}{c}5.1,5.3, \\
5.4\end{array}$ \\
\hline 20 & Is the project revised and accepted? & 1.2 & & & & \\
\hline 21 & $\begin{array}{l}\text { Are you sure of what business units or strategic functions } \\
\text { support the proposal and whether they fit in the strategy? }\end{array}$ & 1.5 & & & & \\
\hline 22 & $\begin{array}{l}\text { Have you analysed and tested the experience on purchase, } \\
\text { construction, etc, for this project? }\end{array}$ & 1.2 & & & & \\
\hline 23 & Is the project plans defined and completed? & 1.4 & & & & \\
\hline 24 & $\begin{array}{l}\text { Is there a detailed planning of resources and a plan of } \\
\text { costs for the design stage? }\end{array}$ & 1.4 & & & & \\
\hline 25 & $\begin{array}{l}\text { Is there a detailed planning of resources and a plan of } \\
\text { costs for the whole project? }\end{array}$ & 1.4 & & & & \\
\hline 26 & Is the project designed to avoid the known risks? & $1.2,1.4$ & & & & \\
\hline 27 & $\begin{array}{l}\text { Have you got the necessary funding to carry out the design } \\
\text { stage? }\end{array}$ & & & 3 & & \\
\hline 28 & Is there is a formal agreement with the parties? & $1.1,1.5$ & & & & \\
\hline 29 & $\begin{array}{l}\text { Is it possible to carry out the project with available } \\
\text { technology? }\end{array}$ & & 2.3 & 3.6 & & \\
\hline 30 & $\begin{array}{l}\text { Has the organization the operational capacity to carry out } \\
\text { the project? }\end{array}$ & 1.5 & 1.5 & & & $\begin{array}{l}5.1,5.3 \\
5.5,5.7\end{array}$ \\
\hline
\end{tabular}


Table 1. Relation between success / failure factors and parameters in the conceptual stage (continued)

\begin{tabular}{|c|c|c|c|c|c|c|}
\hline & Parameters / questions & $\begin{array}{l}\text { Project } \\
\text { Management } \\
\text { factors }\end{array}$ & $\begin{array}{l}\text { Project- } \\
\text { related } \\
\text { factors }\end{array}$ & $\begin{array}{l}\text { External } \\
\text { environmental } \\
\text { factors }\end{array}$ & $\begin{array}{l}\text { Tendering } \\
\text { method }\end{array}$ & $\begin{array}{l}\text { Human- } \\
\text { related } \\
\text { factors }\end{array}$ \\
\hline 31 & Are the objectives clearly defined and completed? & 1.4 & & & & \\
\hline 32 & Do you know how the project success will be tested? & $1.2,1.7$ & & & & \\
\hline 33 & $\begin{array}{l}\text { Is the organization prepared to support the development } \\
\text { of the project? }\end{array}$ & & & 3 & & 5 \\
\hline 34 & Is the project revised and accepted? & 1.2 & & & & 5.10 \\
\hline 35 & Is the project still an attractive and viable business proposal? & & 2.2 & 3 & & \\
\hline 36 & $\begin{array}{l}\text { Is there a detailed planning of resources and a plan of } \\
\text { costs for the tender stage? }\end{array}$ & 1.4 & & & & \\
\hline 37 & $\begin{array}{l}\text { Is there a detailed planning of resources and a plan of } \\
\text { costs for the whole project? }\end{array}$ & 1.4 & & & & \\
\hline 38 & $\begin{array}{l}\text { Are resources available for carrying out the construction } \\
\text { stage? }\end{array}$ & & & 3.1 & & $5.3,5.4$ \\
\hline 39 & Are the important risks eliminated? & $1.2,1.3$ & & & & $5.7,5.9,5.11$ \\
\hline 40 & Are all the tests done and their results accepted? & $1.2,1.7,1.8$ & & & & $5.7,5.8,5.9$ \\
\hline 41 & Is test plan prepared? & $1.4,1.7,1.8$ & & & & \\
\hline 42 & Are the checklists for the users prepared? & $1.4,1.7,1.8$ & & & & \\
\hline 43 & Is the acceptation criteria for the tender stage defined? & 1.2 & & & & 5.8 \\
\hline 44 & Is the project revised and accepted? & 1.2 & & & & 5.10 \\
\hline 45 & Is the project still an attractive and viable business proposal? & & 2.2 & 3 & & \\
\hline 46 & $\begin{array}{l}\text { Is the design process accepted by the company and all } \\
\text { the tests are approved? }\end{array}$ & 1.2 & & & & $5.7,5.8$ \\
\hline 47 & $\begin{array}{l}\text { Are all the expected costs and benefits reviewed according } \\
\text { to the business plan? }\end{array}$ & $1.2,1.3,1.4$ & & & & $5.9,5.11$ \\
\hline 48 & Is the project plan updated and completed? & $1.2,1.3$ & & & & 5.9 \\
\hline 49 & $\begin{array}{l}\text { Is there a detailed planning of resources and a plan of } \\
\text { costs for the construction stage? }\end{array}$ & 1.4 & & & & \\
\hline 50 & $\begin{array}{l}\text { Are resources available for carrying out the finalisation } \\
\text { stage? }\end{array}$ & & & 3 & & \\
\hline 51 & Are the important risks eliminated? & $1.2,1.3$ & & & & $5.7,5.9,5.11$ \\
\hline 52 & Is the project revised and accepted? & $1.2,1.7,1.8$ & & & & $5.7,5.8,5.9$ \\
\hline 53 & $\begin{array}{l}\text { Is the business forecast updated to obtain the emerging } \\
\text { benefits account of the project? }\end{array}$ & 1.3 & & 3.1 & & $5.7,5.9$ \\
\hline 54 & $\begin{array}{l}\text { Is there anybody in charge of monitoring the financial part } \\
\text { and the benefits of the project? }\end{array}$ & 1.5 & & & & 5 \\
\hline 55 & $\begin{array}{l}\text { Are the evaluation methods for measuring the benefits } \\
\text { defined? }\end{array}$ & 1.2 & & & & \\
\hline 56 & Is the budgetary part of the project closed? & 1.9 & & & & \\
\hline 57 & Are all the time, budget and quality analysis defined? & 1.2 & & & & $5.9,5.10$ \\
\hline 58 & Is the project economically examined? & 1.3 & & & & \\
\hline
\end{tabular}

\section{Description of the system}

To analyze the critical success factors in a construction project a SFES is defined. This system should be based on the critical success factors and the parameters /questions described above for all the stages of a project.

Actually, success factor should have repercussions in different project stages. For example, Management skill of project team leaders (variable 5.9) to evaluate the human-related factors affects from the tender stage to the finalization stage of the project and different parameters/questions such as the analysis of risks in different stages (P 39 and 51), the revision of the project in the construction stage (P 52) and the analysis of time, budget and quality in the finalization stage (P 57) analyze this success factor.

Therefore, the System is organized using different spreadsheets for each stage. The parameters are affirmative questions and are located on the left hand side of the spreadsheet. There are as many rows as factors to be evaluated. Three main columns show the results of the evaluation. The first column shows whether the parameter is taken into account or not. Then, a five point scale is used to evaluate the significance of the parameter in the project. The higher the qualification, the more important the parameter is in the project. The last column is just to make comments if they are necessary.

The same evaluation/checklist should be used for each stage of the project together with a general assessment.

To analyze the information of the SFES of each case study, the results are presented on a filing card shown in Figure 3. 


\begin{tabular}{|l|l|l|l||}
\hline $\begin{array}{l}\text { Project: } \\
\text { Stage: }\end{array}$ & YES/NO & $\begin{array}{l}\text { Evaluation } \\
(1-5)\end{array}$ & Comment \\
\hline & & & \\
\hline Parameter 1 & & & \\
\hline Parameter 2 & & & \\
\hline$\ldots$ & & & \\
\hline Parameter n & & \\
\hline General evaluation: [an evaluation of the objectives that have and have not been met] \\
\hline $\begin{array}{l}\text { Improvement possibilities: [an analysis of each stage of the project and the establishment of management improvement } \\
\text { opportunities if necessary] }\end{array}$ \\
\hline
\end{tabular}

Figure 3. Filing card to evaluate the success of a project

\section{Data collection and analysis}

17 industrial construction projects from a variety of contractual arrangements were raldomly selected to be deeply monitored and analyzed from the initial stage until the end of the project using the SFES presented above. The general characteristics of these projects are defined in Table 2 while Table 3 shows the agrupation of these projects by their type: tender projects, projects without thenders, internal projects and external projects.
Each project was analyzed in depth in order to obtain general rules of success and failure, the working methodologies and behaviors for different industrial construction projects in Spain.

The results of this analysis are only an orientation of the industrial construction projects tendency due to the reduced number of case studies. The conclusions are based on comparative and qualitative analyses due to the lack of homogeneity in the sample. Nevertheless, the general idea of the sector behavior is achieved.

Table 2. Informaton from the case study projects

\begin{tabular}{|c|c|c|c|c|}
\hline & Project & Budget & Duration & Characteristics of the evolution of the project \\
\hline 1 & Construction of a waste water treatment facility for a dyeing plant & $0,5 \mathrm{M} €$ & 36 months & $\begin{array}{l}\text { The initial client objectives were totally obtained but there were improvement } \\
\text { opportunities in the conceptual stage of the project that would avoid uncertainties } \\
\text { in the finalization stage. During the conceptual stage the timing and start up of } \\
\text { the project weren't defined. This caused problems in the finalization stage. }\end{array}$ \\
\hline 2 & Construction of a waste water treatment facility for a lamp factory & $0,2 \mathrm{M€}$ & 6 months & $\begin{array}{l}\text { The initial client objectives were totally obtained but there were improvement } \\
\text { opportunities that would have avoided unnecessary risks. In the conceptual } \\
\text { stage the control test for the start up weren't defined. The planning was not } \\
\text { defined and the objectives of the project were unclear so the client could not } \\
\text { evaluate the project until some months after. }\end{array}$ \\
\hline 3 & Construction of a waste water treatment facility for a meat packing plant & $0,2 \mathrm{M} €$ & 6 months & The initial client objectives were totally obtained. \\
\hline 4 & Construction of a wastewater treatment facility for a packing plant & $0,5 \mathrm{M} €$ & 6 months & The initial client objectives were totally obtained. \\
\hline 5 & Construction of a wastewater treatment facility for a chemical plant & $1,5 \mathrm{M€}$ & 10 months & The initial client objectives were totally obtained. \\
\hline 6 & Construction of a mineral water bottling and packing plant & 2,5 M€ & 8 months & The initial client objectives were totally obtained. \\
\hline 7 & Construction of a main sewer, preliminary treatment facility and underwater outlet & $1 \mathrm{M€}$ & 12 months & $\begin{array}{l}\text { The initial client objectives were obtained but there were improvement opportunities } \\
\text { in the tender and construction phases that would have avoided unnecessary } \\
\text { risks. }\end{array}$ \\
\hline 8 & Construction of a diamond saws plant & $0,2 \mathrm{M} €$ & 6 months & The initial client objectives were totally obtained. \\
\hline 9 & Construction of an automating bottling plant & $0,5 \mathrm{M} €$ & 10 months & The initial client objectives were totally obtained. \\
\hline 10 & Construction of an Industrial Treatment Centre & $1,5 \mathrm{M} €$ & 11 months & $\begin{array}{l}\text { Although the setting up of the installations was not completely defined, the initial } \\
\text { client objectives were totally obtained. }\end{array}$ \\
\hline 11 & Construction of a maintenance process of aluminium at high temperatures for energy saving & $0,2 \mathrm{M} €$ & 12 months & The initial client objectives were totally obtained. \\
\hline 12 & Construction of an automating bottling plant & $0,1 \mathrm{M \epsilon}$ & 4 months & The initial client objectives were totally obtained. \\
\hline 13 & Construction of a thermal treatment of aluminium sections plant & $0,5 \mathrm{M} €$ & 11 months & $\begin{array}{l}\text { The client's evaluation of the obtained objectives was positive but if some } \\
\text { organisational aspects of the definition stage were taken into account, the client } \\
\text { would have been more satisfied. }\end{array}$ \\
\hline 14 & Construction of a transport, storage and treatment of aluminium plant & $1 \mathrm{M€}$ & 12 months & $\begin{array}{l}\text { The initial client objectives were totally obtained but there were improvement } \\
\text { opportunities in the design stage of the project that would avoid uncertainties } \\
\text { in the construction stage. }\end{array}$ \\
\hline 15 & Construction of an aluminium plant & $0,2 \mathrm{M} €$ & 12 months & The initial client objectives were totally obtained. \\
\hline 16 & Construction of an industrial channel & 9,5 M€ & 18 months & The initial client objectives were totally obtained. \\
\hline 17 & Construction of an industrial estate water treatment & $0,2 \mathrm{M€}$ & 4 months & The initial client objectives were totally obtained. \\
\hline
\end{tabular}


Table 3. Classification of projects

\begin{tabular}{|l|l||}
\hline Type of project & Project code \\
\hline Tender projects & $1,2,3,4,5,7,9,13,19,20,21$ and 22 \\
\hline Projects without tenders & $6,10,11,12,14,15,16,17$ and 18 \\
\hline Internal projects & $3,6,7,8,10,11,12,13,14,15,16,17,18,21$ and 22 \\
\hline External projects & $1,2,4,5,9,19,20$ \\
\hline
\end{tabular}

Figure 4 and Figure 5 show the summary of the results of evaluating the success of different projects according to their contractual arrangements (lump sum contract vs. contract construction and bidding vs. negotiation contractual arrangement). The results of the evaluation are arranged in columns. For each project there are 58 parameters to be evaluated, which are monitored during each stage of the project and shown in 58 rows. The colored boxes (N) are the parameters of these projects that were not considered during the project. The other boxes $(\mathrm{Y})$ are those parameters of the projects that were considered during the project. The reasons for considering or not these parameters in the different projects are not shown in this table due to the huge amount of information, but the conclusions also refer to this information. For each parameter and depending on the contractual arrangement, a percentage of projects that considered the mentioned parameter $(\% \mathrm{Y})$ and a percentage of projects that didn't consider the mentioned parameter $(\% \mathrm{~N})$ are shown. The objective is to obtain the tendency for each parameter in the different contractual arrangements.

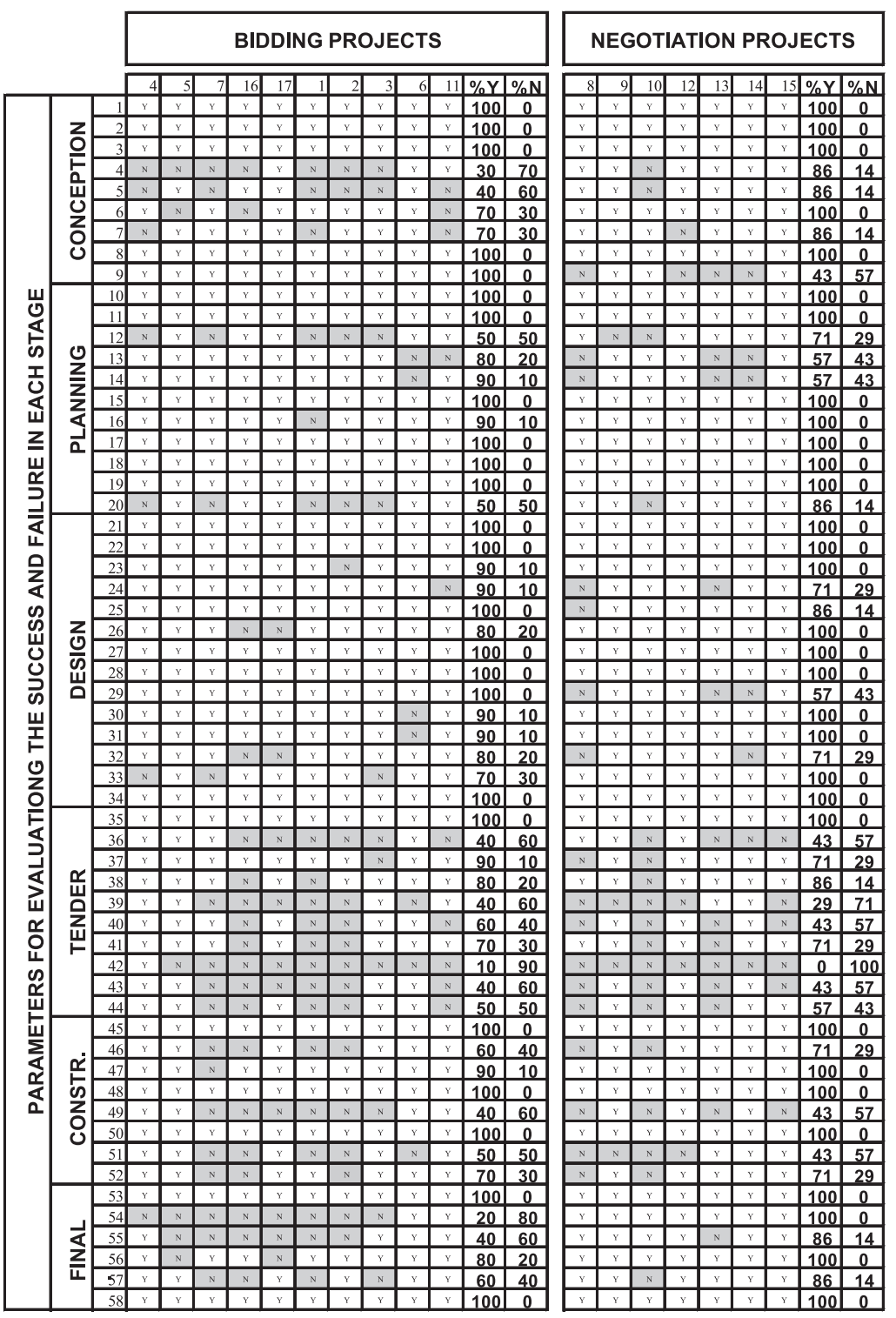

Figure 4. Comparison between projects with a tender process and without a tender process 


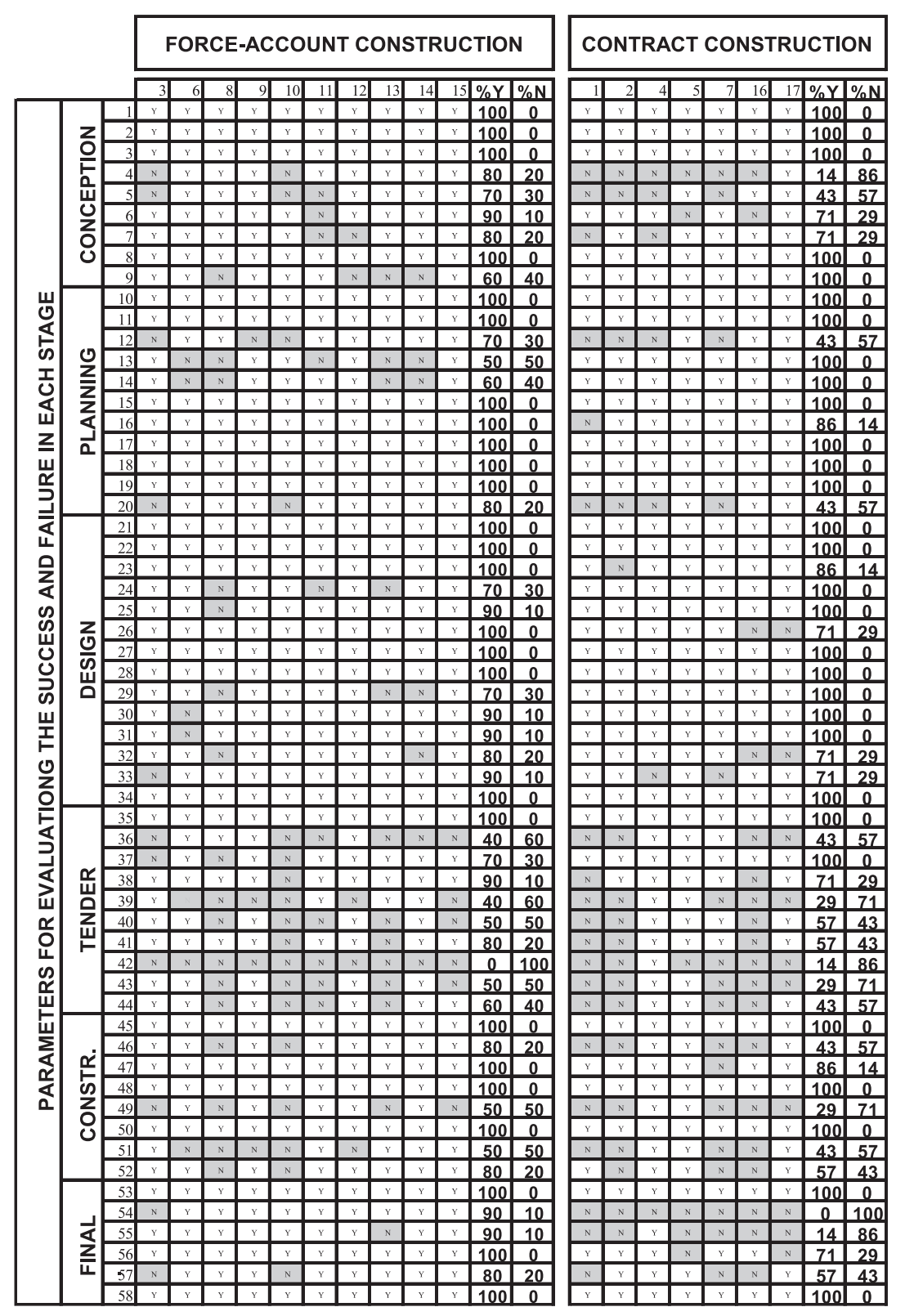

Figure 5. Comparison between internal and external projects 


\section{Results and discussion}

Despite evaluating few case studies, each project was analyzed and compared with the other results in order to obtain general behavior of the Industrial Construction sector and rules of success and failure for different contractual arrangements. Therefore, the conclusions are based on comparative and qualitative analysis due to the lack of homogeneity in the sample.

Basically, between lump sum and contract construction and between bidding and negotiations contracts there are general differences.

In the lump sum contractual arrangement, the client has a direct contractual relationship with most of the participants and the owner retains the maximum amount of control and monitoring the benefits.

On the other hand, in contract construction projects the owner delegates all the responsibilities of design and construction to outside consultants. In order for a contract construction to succeed, the owner must be able to provide a set of unambiguous performance specifications to the contractor and must have complete confidence in the capability of the contractor to carry out the mission. In this kind of projects the contractor is responsible of the project and should develop a detailed planning of time, costs and resources to achieve the owner's objectives.

The owner may also select a general contractor either through competitive bidding or through negotiation. Public agencies are required to use the competitive bidding mode, while private organizations may choose either mode of operation. In using competitive bidding, the owner is forced to use the designer-constructor sequence since detailed plans and specifications must be ready before inviting bidders to submit their bids.

O verall, it was observed that during the design and construction stages, almost all success factors were taken into account. This means that for whatever contractual arrangement not only the construction stage but also the first stages are very important and relevant to achieve the core objectives of the project.

In relation to the Project $M$ anagement factors:

- The areas related to the business necessities and support to the proposal are always taken into consideration, from the beginning of the conceptual stage until the finalization of the project. Rigor in the analysis of the conception stage can lead to great savings in the construction and finalization stages. However, in bidding projects the conceptual studies ( $P$ 4, 5, and 6) and the finalization stage (P 54, 55 and 56) are less strict and there is a lack of rigor in tests and results.

- In general, the competitive advantages and the monitoring of the project are given little importance. Only $14 \%$ of the contract construction projects analyzed the competitive advantage of the proposal in relation to the competitors with similar capacities (P 4). However, contract construction projects consider project planning (P 24) to be more important ( $100 \%$ of the analysed projects) than lump sum projects (70\% of the analysed projects). This is because in contract construction projects problems can appear due to client dissatisfaction. If planning is not undertaken during the design stage the client cannot monitor and control the activities. But, surprisingly, many projects don't plan their resources and costs and at the end, their clients are satisfied with the overall project.

- On the other hand, the control mechanism such as the evaluation methods is defined as very important but lump sum projects give greater importance to monitoring the benefits ( $90 \%$ of the analysed projects) than contract construction projects. In contract construction projects the competitive advantages and project control are not taken into excessive consideration because most of these projects involve tendering.

- In whatever contractual arrangement, the factors such as the definition of the objectives (P 31) the methods to evaluate results ( $P$ 32), the capacity of the organisation to support the project (P 33) and the revision of the project (P 34) are deeply considered.

- Few of the studied projects developed a detailed planning of resources and a plan of cost for the tender stage ( $P$ 36) but when talking about the planning of resources and a plan of cost for the whole project ( $P$ 37 ) the percentage increases a lot. This means that most of the companies make plans of resources and cost for the projects but not for detailed stages of the project. If considered separately, in lump sum projects only $70 \%$ of the companies plan resources and costs whereas in contract construction projects, all companies do. Therefore, it is possible to infer that companies are more convinced of their internal management and functioning than to subcontract the work in which they try to control it by defining the plan of resources and costs of the project.

Referring to the Project related factors:

- The definition of the project is considered very important in whatever contractual arrangement along 
all the stages of the project (P 1 and 2 from the conceptual stage, $P 10$ and 11 from the planning stage, $P 21$ and 22 from the design stage, $P 35$ from the tender stage and $P 45$ from the construction stage).

- Generally, the existing risks are not detected and studied in the first stages of the project (P 26). Normally, the risks should be analyzed in the initial stages, but from the studied projects it is deduced that they are not analyzed until the project is at an advanced stage.

- Lump sum contract projects give more importance to the project characteristics such as the nature, complexity, type and size than contract construction projects.

From the External environment factors:

- All parameters related to the financial and technical parts of the design stage (P 27, 28, 29 and 30) are considered important in all kind of contractual arrangements.

- For the finalization stage, the economical and budgetary analysis (P 56 and 58 ) is very important. All analyzed projects have the budgetary part of the project closed and are economically examined.

- Bidding projects consider the current resources and technology (P 9) with greater rigor $(100 \%$ of the analyzed projects) while in negotiated projects, the technological capacity of the team in the conception stage can be overestimated due to a lack of definition.

In relation to the tendering method factors:

- In all projects, once the main contractor is selected the other parts of the tendering process are drawn aside.

Concerning the Human related factors:

- Client satisfaction is considered very important but in most of the analyzed projects the checklists for clients and users, although they can help to obtain objective evaluations about the work done, are not taken into account. Sometimes, the lack of definition of the client satisfaction might be due to the fact that in some projects the user is still unknown or it is difficult to evaluate the client satisfaction.

- In whatever contractual arrangement the capacity of the organization to support the project and the acceptance of the project is defined as very important.

- The monitoring of the benefits of the project and how to measure them (factors 54 and 55) are considered in nearly all lump sum projects $(90 \%)$. In contract construction projects, they are not emphasized because there is no team involvement (none of the external analyzed projects assigned a person to monitor the financial part of the project). The finalization stage of contract construction projects can be prolonged in time while in lump sum projects the closing of the project is established previously.

Generally, the results of this SFES obtained above agree with the impressions obtained from personal contacts with the people in charge of these projects.

\section{Conclusions}

This paper has analyzed different classification schemas to classify critical success factors with the aim to develop a methodology to evaluate projects and extract conclusions from the characteristics in Industrial Construction projects using different contractual arrangements.

An existing theoretical model (Chan et al., 2004) was used as a basis for the evaluation. Therefore, one of the objectives was to validate this theoretical model into Industrial Construction Projects.

From this analysis, we observed that such a generic model was suitable for Industrial Construction Projects with different contractual characteristics.

We also observed that in Industrial Construction projects, not only the construction stage is where the success of the project is achieved. Therefore, although the construction stage has been the focus of many studies, the first stages are decisive for the success on the whole project. It is during the construction stage that the demands for time, cost and quality requirements become most acute. In practice when a project comes to the construction stage, all the past inadequacies of every preceding stage appear and everything must be done within the schedule and budget given. We must therefore be aware that there are important issues that must be properly addressed in the preceding stage.

Furthermore, it can be observed from the analyzed experiences that the degree of effectiveness of the project management functions and the degree of success of the human related factors in Industrial Construction projects in Spain are very relevant for the success of the project. Therefore, research and development should focus on systems aimed to improve project management such as communication, planning or monitoring systems. 
Moreover, the project manager experience and the knowledge of the different stakeholders are also critical for the success of Industrial Construction projects. Academics should work to provide the necessary knowledge and basically project management techniques to the future professionals of the construction sector.

It is expected that this analysis will serve as a basis for improving current practices in Industrial Construction projects and for informing those companies, who are interested in getting into the Spanish market, of the characteristics and current situation of such specialised sector.

\section{References}

Avots I. (1969), Why does project management fail? California Management Review, 77-82.

Baker. B, M urphy D. and Fisher D. (1983), Factors affecting project success. Project M anagement $\mathrm{H}$ andbook, Van Nostrand Reinhold Co., N ew York

Belassi W. and Tukel O. (1996), A new framework for determining critical success/failure factors in projects. Int. J. Proj. Manage., Vol. 14, No. 3, pp. 141-151.

Belout A. (1998), Effects of human resource management on project effectiveness and success: toward a new conceptual framework. Int. J. Proj. Manage., 16: 1, 21-26.

Brown A. and Adams J. (2000), Measuring the effect of project management on construction outputs: a new approach. Int. J. Proj. Manage., 18: 5, 327-335.

Chan A. (1996), D eterminants of project success in the construction industry of Hong Kong. PhD thesis, Univ. of South Australia.

Chan D. and Kumaraswamy M. (1997), A comparative study of causes of time overruns in Hong Kong construction projects. Int. J. Proj. Manage., 15: 1, 55-63.

Chan A. P. C., Scott D. and Chan A. P. L. (2004), Factors affecting the success of a Construction Project. J. Constr. Engrg. and M gmt., 130: 1, 153-155.

Chua D., Kog Y. and Loh K. (1999), Critical success factors for different project objectives. J. Constr. Eng. Manage., 125: 3, 142-150.

Clough R. H., Sears G. A. and Sears S. K. (2000), Construction Project Management. 4th edition, John Wiley and Sons..

Dissanayaka S. and Kumaraswamy M. (1999), Evaluation of factors affecting time and cost performance in Hong Kong building projects. Eng., Constr. Archit. Manage., 6: 3, 287-298.

Freeman M. and Beale P. (1992), Measuring project success. Proj. Manage. J., 23: 1, 8-17.
Gann D. and Whyte J. (2003), Design quality, its measurement and management in the built environment. Building Research \& Information, 31:5 (314-317) Kumaraswamy M. and Chan D. (1999), Factors facilitating faster construction. J. Constr. Procure., 5: 2, 88-98.

Lim C. and Mohamed M. (1999), Criteria of project success: An exploratory re-examination. Int. J. Proj. Manage., 17: 4, 243-248.

Maloney W. F. (1990), Framework for analysis of performance. J. Constr. Eng. Manage., 116: 3, 399-415.

N ew combe R. (2000), The anatomy of two projects: A comparative analysis approach. Int. J. Proj. Manage., 18: 3, 189-199.

Özdogan I. and Birgönül M.T. (2000), A decision support framework for project sponsors in the planning stage of Build-O perate-Transfer (BOT) Projects. Construction Management and Economics, 18, p.343-353.

Pinto J. and Prescott J. (1990), Planning and tactical factors in the project implementation process. J. M anagement Studies, 305 -325.

Pinto J. and Slevin D. (1989), Critical success factors in $R \& D$ projects. Res. Technol. Management, pp. 31-35.

Pocock J., Liu L. and Tang W. (1997a), Prediction of project performance based on degree of interaction. J. M anage. Eng., 13: 2, 63-76.

Pocock J., Liu L. and Kim M. (1997b), Impact of management approach on project interaction and performance. J. Constr. Eng. Manage., 123: 4, 411-418.

Riggs J., Goodman M., Finley R. and Miller T. (1992), A decision support system for predicting project success. Proj. Manage. J., 22: 3, 37-43.

Rubin I. and Seeling W. (1967), Experience as a factor in the selection and performance of project managers. IEEE Trans. Eng. Management, 14 (3) 131-134. SEO PAN (2007), La construcción en 2006. Resultados del sector de la construcción 2006. O bservatorio del sector de la construcción.

Schultz R., Slevin D. and Pinto J. (1987), Strategy and tactics in a process model of project implementation. O Interfaces, 17(3) 34-46.

Songer A. and Molenaar K. (1997), Project characteristics for successful public-sector design-build. J. Constr. Eng. Manage., 123: 1, 34-40.

Shenhar A., Levy O . and Dvir D. (1997), Mapping the dimensions of project success. Proj. Manage. J., 28: 2, 5-13.

Walker D. (1995), An investigation into construction time performance. Constr. Manage. Econom., 13: 3, 263-274.

Walker D. and Vines M. (2000), Australian multi-unit residential project construction time performance factors. Eng., Constr. Archit. Manage., 7: 3, 278-284. 